\title{
Iranian paper sparks sense of déjà vu
}

A review paper by Massoumeh Ebtekar, the former vice-president of Iran and an immunologist at Tarbiat Modares University in Tehran, is to be retracted from an Iranian journal following allegations that it was almost entirely stitched together from other scientists' papers.

The paper came to light after a Nature News article about the Deja Vu web database at the University of Texas Southwestern Medical Center at Dallas, which lists articles with potential plagiarisms (see Nature 455, 715; 2008). Among the resulting spike in hits, Harold Garner's team, which runs the database, noticed many came from Farsi-language forums and blogs in Iran (see http://alef.ir/ content/view/32958).

What triggered Iranians' interest was an entry about a paper on cytokines and air pollution, published in 2006 in the Iranian Journal of Allergy, Asthma and Immunology (M. Ebtekar Iran. J. Allergy Asthma Immunol.

\section{BEE STING}

Crop yields unaffected by pollinator declines. www.nature.com/news

5, 47-56; 2006). Deja Vu claims that about 85\% of the text comes from five papers by other researchers, with the chunks ranging from $5 \%$ to $30 \%$ of their content.

The sole author of the paper was Ebtekar, who served as spokeswoman for the militant students holding 52 Americans hostage in the US Embassy in Tehran during 1979-81. She went on to become vice-president in 1997 under reformist president Mohammad Khatami, and was elected to Tehran City Council in 2007.

Ebtekar was unavailable for
"The article is a veritable patchwork of other people's work, word for word." shortcomings and mistakes. I will take more care in writing my articles and preparing my manuscripts." Publishing the entry on Deja Vu, she said, went "too far in condemning people and smearing their reputation before they have a chance to respond".

Ian Mudway, a toxicologist at King's College London who authored an earlier paper cited by Deja Vu in Ebtekar's work and extensively copied in her paper, isn't impressed. "The article is a veritable patchwork of other people's work, word for word, grammatical error for comment and did not respond to e-mail queries from Nature. But she admitted in a written response to Deja $\mathrm{Vu}$, now posted on her own Farsi-language blog, that some paragraphs had been taken "without due reference to the authors which is a clear mistake". She blamed this on a student whom she says helped her with the manuscript. "I have apologized for my grammatical error," he says.

Mohammad Eslami, editor-in-chief of the Iranian Journal of Allergy, Asthma and Immunology, told Nature that the article will be retracted and that the journal will publish an editorial re-emphasizing its policy on the duplication of published material.

Declan Butler 